\section{Stimulerende oppdatering om autisme}

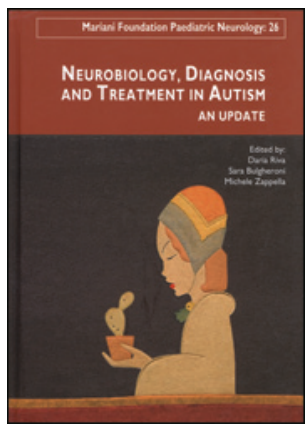

Daria Riva, Sara Bulgheroni,

Michele Zappella, red.

Neurobiology, diagnosis and treatment

in autism

An update. 232 s, tab, ill. Montrouge:

John Libbey Eurotext, 2013. Pris EUR 64

ISBN 978-2-7420-0836-0

Autisme som klinisk begrep har overlevd i mer enn 70 år på tross av stadig endrede diagnosekriterier, ekstremt variert klinikk, et vell av komorbiditeter, fravær av objektive markører, ukjent(e) etiologi(er) og alternative betegnelser som «gjennomgripende utviklingsforstyrrelse» med mer. Selv om begrepet har overlevd, har oppfatningene om tilstanden endret seg dramatisk underveis. Fra å være svært sjelden og å manifestere seg i tidligste barndom er autisme nå ansett for å forekomme hyppig (1\%), og svært mange får diagnosen i godt voksen alder. Fra spekulasjoner om at autisme er en psykologisk reaksjon (på «den kolde mor»), tar man i dag for gitt at autisme er en nevrobiologisk utviklingsforstyrrelse. Fra maktesløshet og apati innen helsevesenet fokuseres det i dag på evidensbaserte psykososiale behandlingsformer, og vi kan ha fătt den første effektive medikamentelle behandlingen for kjernesymptomer ved autisme.

Boken består av 22 kapitler skrevet av til sammen 36 ulike forfattere. Den er delt inn i fire hovedbolker: nevrobiologi, psykofarmakologi, rehabilitering og komplementære og alternative terapier.

Den nevrobiologiske delen er delt inn i sju underkapitler med hovedvekt på avansert nevrologisk bildediagnostikk, genetikk, interaksjon genmiljø, nevrotransmisjon (GABA og oxytocin) og immunologi. Forfatterne berører patoanatomiske autopsifunn, og de omtaler assosiasjoner mellom immunologiske responser hos mor og sannsynlig affeksjon av den tidligste celledifferensiering og synapsedannelse i fosterets hjerne. Defekter i cerebrale nettverkforbindelser (connectivity) har fått stor plass, og et sannsynlig dysfunksjonelt «speilnevronsystem» settes i sammenheng med utvikling av autismespekterforstyrrelse. Kapitlene føyer seg fint inn i hverandre og beskriver hvordan svært mange subtile biologiske avvik i dag kan kobles sammen med autismespekterforstyrrelse. Den som håper på enkle årsaksforklaringer, vil bli skuffet.

Psykofarmakologidelen består av kun to kapitler: ett om legemidler i klinisk praksis og ett om fremtidige perspektiver på legemiddelbehandling av kjernesymptomer ved autisme. Dette er ikke tilfeldig. Vi har i dag simpelthen ikke gode legemidler for autisme. For en kliniker vil behandlingen oftest rettes mot assosiert atferdsproblematikk som hyperaktivitet, aggresjon, stemningssvingninger, selvskading og, av og til, psykoser. (For ikke å snakke om epilepsi, som ikke er nevnt i boken.) Medikamentell behandling av kjernesymptomene vansker med sosial interaksjon og redusert kommunikasjonsevne er foreløpig ikke tilstrekkelig evidensbasert, men kliniske studier viser lovende resultater av tilførsel av oxytocin i form av bedret sosial interaksjonsevne.
Delen «Rehabilitation» består av ti kapitler og presenterer ulike behandlingstilnærminger primært utarbeidet for barn, herunder Treatment and Education of Autistic and related CommunicationHandicapped Children (TEACCH), Developmental Individual Relationship-based Model (DIR) og anvendt atferdsanalyse (Applied Behaviour Analysis, ABA), som for øvrig også benyttes hyppig hos voksne, spesielt ved utfordrende atferd. I denne delen omtales også tidlig psykomotorisk intervensjon hos barn, sosial ferdighetstrening og metoder som fokuserer på læring og mestring. Siden atferdsmodifikasjon basert på funksjonell atferdsanalyse og behavioristisk tenkning, historisk sett har vært kontroversiell, understrekes det at slike tilnærminger i dag i stor grad er evidensbasert.

Den siste delen, om komplementære og alternative terapier, tar for seg ulike diettbehandlinger (gluten- og/eller kaseinfrie dietter), kostholdssupplement, vitaminer, antibiotika og fungicide behandlinger. Dette er behandlingsformer som har mangelfull vitenskapelig dokumentasjon, og det konkluderes pedagogisk med at man per i dag ikke kan anbefale slike behandlingstiltak ved autisme.

For en kliniker er særlig den nevrobiologiske forskningen innenfor feltet uoversiktlig. En bok som forsøker å samle trådene, er derfor velkommen. Med så mange medforfattere er det ikke til å unngå at den pedagogiske evnen til formidling varierer noe. Boken er likevel lettlest. Riktignok forekommer det en del gjentakelser, men disse kommer i ulike kontekster og kan snarere enn å irritere bidra til at leseren făr et mer integrert syn på biologi og klinikk ved autisme.

Boken vil alt i alt være stimulerende lesning for alle fagfolk som til daglig arbeider med autismespekterforstyrrelser. Det eneste jeg finner å måtte påtale, er at delen «Rehabilitation» burde hett «Habilitation», for det er i realiteten det all behandling ved autismespekterforstyrrelser i dag dreier seg om. Ordet kommer fra latinsk habilis (dyktig) og kan oversettes med «dyktiggjøring».

Nils Olav Aanonsen

Avdelingsoverlege, Avdeling for nevrohabilitering

Oslo universitetssykehus 